\title{
NGO Pasifika Renaissance Shares More Than 200 Stories from Pohnpei, Micronesia on Youtube
}

\author{
Takuya Nagaoka* \\ Executive Director, NGO Pasifika Renaissance, Japan
}

Submission: November 09, 2017; Published: February 01, 2018

*Corresponding author: Takuya Nagaoka, Executive Director, NGO Pasifika Renaissance, Japan, Email: takuya.nagaoka@gmail.com

\section{Opinion}

POHNPEI, Federated States of Micronesia (Kaselehlie Press, May 20, 2017) Pasifika Renaissance was established in September 2014 in Japan as an NGO, with a mission to preserve and promote cultural and historical heritage in the Pacific Islands. We aim to revitalize traditional culture and empower local communities. We work in three main fields: documenting, researching, and teaching about traditional cultures and cultural heritage; providing technical assistance to relevant agencies and organizations; and promoting tourism. You can find out more at our Facebook page, where we post cultural and historical information such as historical photos and educational materials and share updates on our organization's activities.

We are currently engaged in a major project to document oral tradition in Pohnpei State. Many older Micronesians have fond childhood memories of listening to stories told by elderly relatives before bed. This practice, however, has been largely lost in Pohnpei due to the spread of new media such as videos and games and the decline of the younger generation's interest in traditional culture.

In order to document stories from knowledgeable elders and pass them down to younger generations, Pasifika Renaissance began filming those stories in 2015 sharing the videos on our YouTube channel with kind permission from the FSM Office of National Archives, Culture and Historic Preservation. This method of documenting and sharing traditional knowledge through online media is rare in the Pacific Islands. However, we believe that it has a great potential for future applications due to the relative ease of use and the Internet's global reach. Our project has been welcomed and supported by traditional chiefs, elders and other community members, who share our concern that traditional knowledge could be lost.

We are very happy to announce that we have now uploaded more than 200 narrative videos on our YouTube channel. These stories include legends, traditional tales, historical events, customs, chants and songs from Pohnpei (9 videos), Pingelap
(69), Mwoakilloa (11), Sapwuahfik (60), Nukuoro (25), and Kapingamarangi (25), as well as two island groups of Chuuk State: the Mortlock Islands (10) and Namonuito (16). Soon, we hope to add more videos from Pohnpei, where we began our work just this year in collaboration with the Division of Historic Preservation and Cultural Affairs, Pohnpei State Department of Land.

Our YouTube channel has attracted over 150,000 views. Of these views, $78.5 \%$ are from United States, where one third of FSM citizens now reside. $12 \%$ of our views come from within the FSM. Our YouTube channel has now reached 1,250 views per day, which we believe suggests a keen interest in these stories.

We would like to thank our storytellers and others who have supported this project, as well as generous donors such as the KDDI Foundation in Japan. We hope by watching these videos, people can continue to pass on these stories to their children and younger relatives.

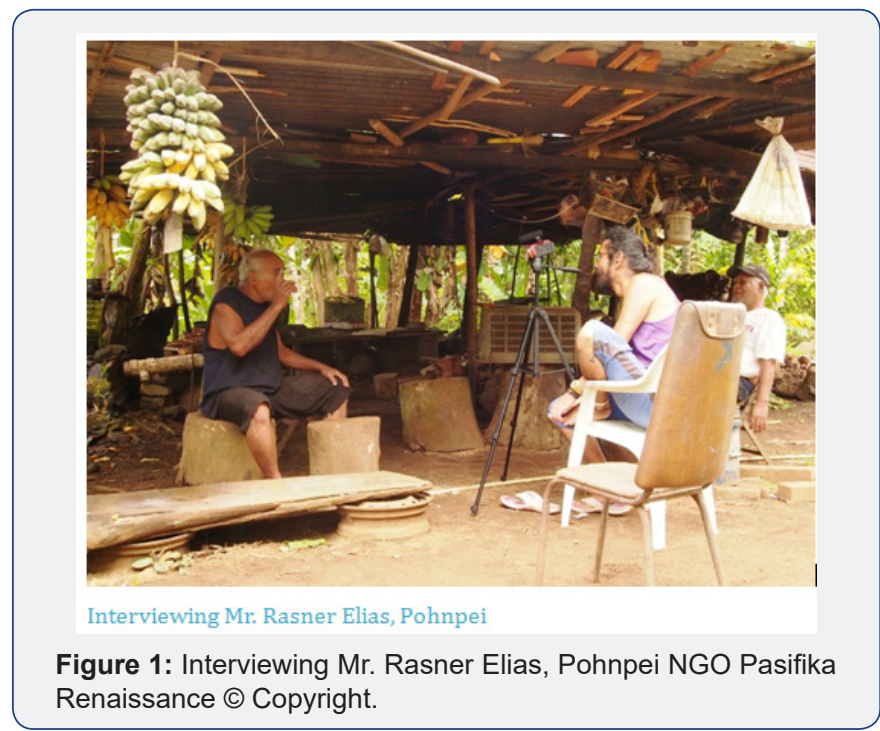

If you would like to contribute stories or know someone who is willing to share stories with us, please contact us or by phoning 
the above Division (320-2652). If you have a knowledgeable elderly relative or friend staying overseas and have the ability to record his/her story via cellphone, tablet or digital camera, please let us know. Please follow us on Facebook and our YouTube channel to receive updates as this project develops (Figure 1).
We plan to extend this project to other states in the FSM and other Pacific regions in the near future, and hope to collaborate with researchers, government agencies, NGOs, and community members. Please get in touch, and let us know how you can help spread this "renaissance" movement!

\section{Your next submission with Juniper Publishers will reach you the below assets}

- Quality Editorial service

- Swift Peer Review

- Reprints availability

- E-prints Service

- Manuscript Podcast for convenient understanding

- Global attainment for your research

- Manuscript accessibility in different formats

( Pdf, E-pub, Full Text, Audio)

- Unceasing customer service

Track the below URL for one-step submission https://juniperpublishers.com/online-submission.php 